\title{
Fiscal Policies and Challenges in South Asia
}

\author{
Raghbendra Jha, \\ Australia South Asia Research Centre \\ Australian National University
}

\begin{abstract}
This paper presents a brief overview of the extant fiscal situation in South Asian countries. In particular, I emphasize low tax/GDP ratios and inelastic expenditure/GDP ratios which then lead to structurally entrenched fiscal deficits. The paper also reports on the sustainability of fiscal and current account deficits in the South Asian countries. Finally, the paper reports on some important issues in tax reform in South Asian counties. These include explaining and finding an antidote for low tax/GDP ratios and analyzing the scope for a VAT. Some general principles are enunciated but many of the required reforms have to be context specific.
\end{abstract}

Keywords; South Asia, Fiscal Policy, VAT

JEL Classification Code: H30, H 50, H 62, H 63

All correspondence to:

Prof. Raghbendra Jha, ASARC, Arndt-Corden Division of Economics, College of Asia and the Pacific, Australian National University, Canberra, ACT 0200, Australia Phone: + 61261252683

Fax: + 61261250443

Email :r.jha@anu.edu.au 


\section{Introduction}

Fiscal policy plays several important roles in many developing countries, including those in South Asia. These roles include financing the current and developmental budgets of the government, stabilizing national income and output, redistributing incomes and resources ensuring efficient production and trade of goods and services, amongst a host of others. Clearly, large quantities of resources have to be raised and spent efficiently. In addition, the gap (typically negative) between public expenditure and revenues must be sustainable in the sense that the debt/GDP ratio reaches a finite limit and is serviced efficiently.

Furthermore, as events since the onset of the ongoing global financial crisis have reminded us, economic crises have serious impacts upon the poor. ${ }^{1}$ In the relative absence of efficient market forces, widespread poverty and inadequate private sector resources the state is invariably called upon to address human development requirements the need for which gets exacerbated during economic crises. This further underscores the critical importance of fiscal policy.

This chapter provides an overview of some of the key fiscal issues facing the major countries of South Asia: Bangladesh, India, Nepal, Pakistan and Sri Lanka and is organized as follows. In section II I discuss some of the key characteristics of government revenue and expenditure in South Asian countries. Section III considers issues related to the sustainability of the fiscal deficit in many of these countries. Section IV considers some emerging challenges facing South Asian countries and section V concludes.

\section{Revenue and Expenditure Profile of South Asian Countries}

Given the enormous responsibilities reposed in fiscal policy it is important to note that resources available for fiscal policy in South Asian countries in particular and developing countries in general are quite meager. This has the consequence that expediency (in the sense of being easy to tax) rather than efficiency considerations often guide tax decisions. Further, political pressures for specific public expenditures, in particular often poorly targeted and wasteful current subsidies, are intense and hard to resist. Jha (2009b) discusses these issues in some detail in the context of developing counties and most of these arguments apply to the case of South Asian countries as well. 
Table 1 presents an overview of the central government finances in South Asia vis a vis some other major country groupings.

Table 1: Fiscal Position of South Asian Countries (Central Governments) in Comparative Perspective

\begin{tabular}{|c|c|c|c|c|c|c|c|c|c|c|c|c|}
\hline \multirow[t]{3}{*}{ Country } & \multicolumn{2}{|c|}{$\begin{array}{l}\text { Revenue } \\
\text { ( } \% \text { of GDP) }\end{array}$} & \multicolumn{2}{|c|}{$\begin{array}{l}\text { Expense } \\
\text { (\%of GDP) }\end{array}$} & \multicolumn{2}{|c|}{$\begin{array}{l}\text { Cash surplus } \\
\text { or deficit } \\
(\% \text { of GDP) }\end{array}$} & \multicolumn{4}{|c|}{$\begin{array}{l}\text { Net Incurrence of Liabilities } \\
\text { (\% of GDP) }\end{array}$} & \multicolumn{2}{|c|}{$\begin{array}{l}\text { Debt and Interest } \\
\text { Payments }\end{array}$} \\
\hline & \multirow[b]{2}{*}{1995} & \multirow[b]{2}{*}{2007} & \multirow[b]{2}{*}{1995} & \multirow[b]{2}{*}{2007} & \multirow[b]{2}{*}{1995} & \multirow[b]{2}{*}{2007} & \multicolumn{2}{|c|}{ Domestic } & \multicolumn{2}{|c|}{ Foreign } & \multirow{2}{*}{$\begin{array}{c}\text { Total Debt } \\
\text { (\% of GDP }\end{array}$} & \multirow{2}{*}{$\begin{array}{c}\begin{array}{c}\text { Interest } \\
\text { (\% of } \\
\text { revenue) }\end{array} \\
2007\end{array}$} \\
\hline & & & & & & & 1995 & 2007 & 1995 & 2007 & & \\
\hline Bangladesh & & 10.3 & & 10.1 & & -1.3 & & 2.4 & & 0.5 & & 20.7 \\
\hline India & 12.3 & 13.6 & 14.4 & 15.3 & -2.2 & -1.4 & 5.1 & 2.8 & 0.0 & 0.2 & 53.7 & 23.9 \\
\hline Nepal & 10.5 & 11.9 & & 15.1 & & -1.0 & 0.6 & 1.2 & 2.5 & 0.3 & 43.0 & 6.0 \\
\hline Pakistan & 17.2 & 14.4 & 19.1 & 16.2 & -5.3 & -4.1 & & & & & & 29.2 \\
\hline Sri Lanka & 20.4 & 15.8 & 26.0 & 20.1 & -7.6 & -6.5 & 5.2 & 4.2 & 3.2 & 2.8 & 85.0 & 30.7 \\
\hline $\begin{array}{l}\text { Middle income } \\
\text { countries }\end{array}$ & 16.4 & 18.2 & & 18.6 & & -1.5 & & 1.0 & & 0.0 & & 5.6 \\
\hline $\begin{array}{l}\text { Lower middle } \\
\text { income countries }\end{array}$ & 11.9 & 16.2 & & 16.1 & & -1.1 & & 1.1 & & 0.1 & & 5.6 \\
\hline $\begin{array}{l}\text { Upper middle } \\
\text { income countries }\end{array}$ & & & & & & & & 0.3 & & 0.4 & & 4.8 \\
\hline South Asia & 13.1 & 13.5 & 15.3 & 15.1 & -2.7 & -1.8 & 3.8 & 2.6 & 1.1 & 0.4 & 53.7 & 22.3 \\
\hline High income & & 27.0 & & 28.0 & & -1.0 & & & & & 44.0 & 5.2 \\
\hline
\end{tabular}

Source: Government Finance Statistics, IMF

Revenue to GDP ratios for South Asian countries are less than half that for rich countries and even lower than those for lower middle income countries. India and Nepal registered an increase in their revenue to GDP ratios over time whereas Pakistan, Bangladesh and Sri Lanka experienced a drop in this ratio. Thus, public resources are low in the South Asian countries and in some countries there has actually been deterioration in their revenue performance over time.

Public expenditure to GDP ratio in high income countries is almost twice as high as in South Asian countries. Even low middle income countries had higher public expenditure to GDP ratio than South Asian countries. Between 1995 and 2007 public expenditure to GDP ratio rose in India but actually fell in Pakistan and Sri Lanka, partly because of the squeeze in revenue in these two countries.

As a consequence of this contemporaneous cash deficits following from budgets were higher in South Asia than those even in low middle income countries. However, deficits for the South Asia have come down although they remain at high levels in Pakistan and Sri Lanka. 
As a consequence of the accumulation of such deficits there was positive net incurrence of liabilities in these countries. Net domestic liabilities were higher than foreign liabilities for all countries in all time periods indicating that, despite thin domestic bond markets, South Asian countries preferred to borrow domestically rather than from abroad. The accumulation of both domestic and foreign liabilities fell between 1995 and 2007. Debt as a percentage of GDP was 53.7 per cent for South Asia in 2007, not much higher than the high income country figure of 44.0 per cent. Sri Lanka, with a debt-GDP ratio of 85 per cent stood out. Since interest rates in South Asian countries are typically higher than in high income countries interest payment on debt was of a high magnitude. The high income country figure was 5.2 per cent of GDP whereas for South Asia this figure stood at more than four times that at 22.3 per cent. In consonance with their high debt levels, interest payments on debt were particularly high for Pakistan and Sri Lanka.

Thus, table 1 coveys the message that South Asian countries face considerable resource constraints to finance public expenditures which, despite being urgently required, are well below levels for high income and even lower middle income countries. South Asian countries face considerable constraints on the financing of the deficits that result from their expenditures being in excess of their revenues.

In Table 2 I describe the structure of public expenditure in the South Asian countries. This table shows the allocation of public expenditure across different categories of expenditure and helps clarify some notions about the structure of South Asian public expenditure. First, from a cross-country perspective South Asian countries do not spend an inordinately high amount on subsidies. In 2007 subsidies as a percentage of GDP were lower ${ }^{2}$ in South Asia than in lower middle income countries, middle income countries, upper middle income countries and high income countries. Indeed, this percentage rose with the income of the income class considered and reached a peak of 62 per cent for high income countries. However, and second, subsidies rose between 1995 and 2007 in South Asian countries. Third, commensurate with their high debt levels, interest expenses are very high in South Asian countries. In 2007 these were more than 4 times as high income and upper middle income countries. Even lower middle income countries have substantially lower interest expenses as compared to South Asian countries. Finally, higher expenditures on goods and services and on compensation of employees form part of the explanation for higher deficits in South Asian countries. 
Table 2: Central Government Expenses (per cent of total)

\begin{tabular}{|l|c|c|c|c|c|c|c|c|c|c|}
\hline $\begin{array}{l}\text { Countryl } \\
\text { Group }\end{array}$ & \multicolumn{2}{|c|}{ Goods and Services } & \multicolumn{2}{c|}{$\begin{array}{c}\text { Compensation of } \\
\text { Employees }\end{array}$} & \multicolumn{2}{c|}{ Interest Payments } & \multicolumn{2}{c|}{$\begin{array}{c}\text { Subsidies and other } \\
\text { transfers }\end{array}$} & \multicolumn{2}{c|}{ Other Expenses } \\
\hline & 1995 & 2007 & 1995 & 2007 & 1995 & 2007 & 1995 & 2007 & 1995 & 2007 \\
\hline Bangladesh & & 13 & & 25 & & 22 & & 29 & 11 \\
\hline India & 14 & 12 & 10 & 7 & 27 & 21 & 33 & 36 & 0 & 1 \\
\hline Nepal & & & & & & 7 & & & & \\
\hline Pakistan & & 31 & & 4 & 28 & 26 & 2 & 31 & & 8 \\
\hline Sri Lanka & 23 & 11 & 20 & 30 & 22 & 25 & 24 & 23 & 10 & 10 \\
\hline Middle Income & & 13 & & 24 & & 6 & & 34 & & 7 \\
\hline $\begin{array}{l}\text { Lower Middle } \\
\text { Income Countries }\end{array}$ & & 13 & & 28 & & 6 & & 34 & & 7 \\
\hline $\begin{array}{l}\text { Upper Middle } \\
\text { Income Countries }\end{array}$ & 17 & 12 & 25 & 20 & 14 & 5 & & 57 & & 8 \\
\hline South Asia & & 13 & & 25 & 27 & 22 & 24 & 29 & & 8 \\
\hline High Income & 8 & 9 & 14 & 13 & 9 & 5 & 63 & 62 & 3 & 6 \\
\hline
\end{tabular}

Source: Government Finance Statistics, IMF

It is interesting to underscore the role of debt servicing in claims on the resources of South Asian countries. This is depicted in Figure 1.

Figure 1: Public and Policy Debt Service as \% of Gross National Income

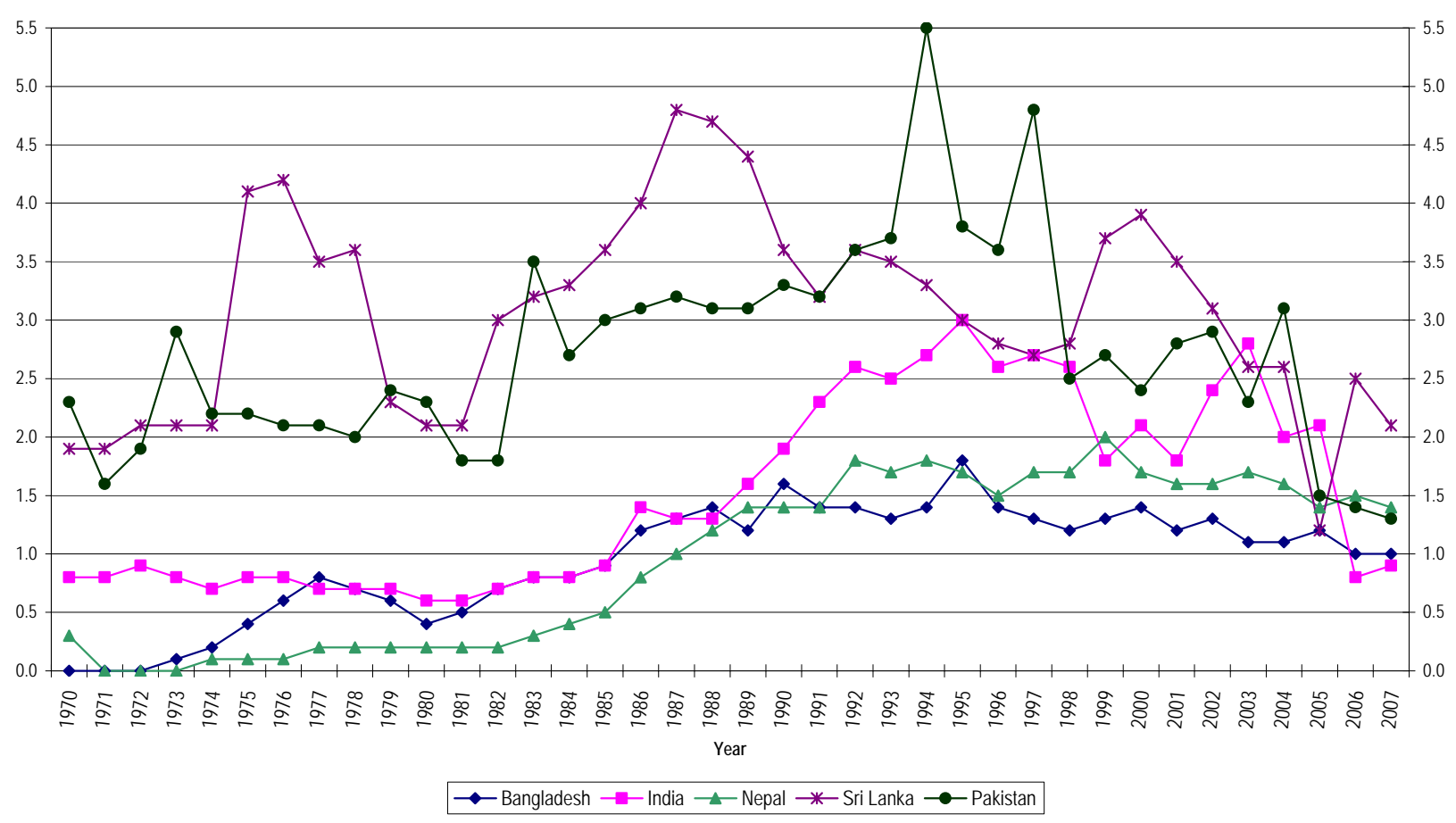


The burden of debt servicing in each of the South Asian countries has had a unique (to each country) peak. Bangladesh’s debt service peaked at 1.8 per cent of GNI in 1995 and dropped to 1 per cent in 2007, ten times the level in 1973. India's debt servicing peaked at 3 per cent of GNI in 1995 and fell sharply to 0.9 per cent in 2007, almost the same level as in 1970 when the economy was much more planned and much less market oriented. In the case of Nepal debt servicing peaked at 2 per cent of GNI in 1998 and then started falling. However, it had fallen only to 1.4 per cent of GNI by 2007. Pakistan’s debt servicing peaked at a staggering 5.5 per cent of GNI in 1994 and then started to drop, falling to 1.3 per cent in 2007. The peak of Sri Lanka's debt servicing was relatively flat with debt servicing remaining at or above 4 per cent in 1975, 1976, 1986, 1987 and 1988. The peak itself occurred at 4.8 per cent in 1987. Even in 2007 this ratio was high at 2.1 per cent. Clearly, high values of debt in the South Asian countries remain a matter of concern.

High levels of debt must ultimately be financed by tax revenues and/or by further borrowing, in which case the debt servicing problem gets exacerbated in the future. It is, therefore, pertinent to ask here whether debt servicing in particular, and revenue raising in general are being conducted in an efficient manner.

An indication of the effectiveness of public expenditure can be had from Table 3 which depicts transparency, accountability and corruption in the public sector on a scale of 1 (low) to 6 (high).

Table 3: CPIA transparency, accountability, and corruption in the public sector rating (1=low to $6=$ high)

\begin{tabular}{l|c|c|c|c|}
\cline { 2 - 4 } & 2005 & 2006 & 2007 & 2008 \\
\cline { 2 - 4 } Bangladesh & 2.5 & 2.5 & 3.0 & 3.0 \\
\cline { 2 - 4 } India & 3.5 & 3.5 & 3.5 & 3.5 \\
\hline Nepal & 2.5 & 3.0 & 3.0 & 3.0 \\
\hline Pakistan & 2.5 & 2.5 & 2.5 & 2.5 \\
\hline Sri Lanka & 3.5 & 3.5 & 3.0 & 3.0 \\
\hline
\end{tabular}

Source: World Development Indicators 2009

Bangladesh's score improved after 2006 but remained stagnant thereafter. India is the best performer among all these countries but has shown no improvement in its performance between 2005 and 2008. Nepal's performance improved after 2005 but remained stagnant thereafter. Pakistan's performance has been the worse among the South Asian nations 
whereas Sri Lanka’s performance was comparable to India’s in 2005 and 2006 but then deteriorated.

In consonance with the observed pattern of public expenditure the structure of government revenue in South Asian countries shows considerable distortions. Public economics theory argues that an efficient form of taxation is one in which most taxes are collected by direct taxes (those on incomes, profits and capital gains). Commodity taxes, especially non-uniform commodity taxes, are distortionary since they affect the incentives to produce a given basket of goods. Further, since everyone. The poor as well as the rich, pays the same rate of tax commodity taxes are also regressive. It is also well known (Sah, 1983; Jha, 2009a) that the extent of re-distribution possible through commodity taxation, e.g., by taxing luxuries at higher rates than necessities is limited. Hence, the greater the proportion of revenue collected from direct taxes the better. Furthermore, commodity tax revenues should be collected ${ }^{3}$ from uniform, non-distortionary taxes such as a Value Added Tax (VAT). In line with liberal economic thinking trade taxes should be kept to a minimum and free trade encouraged.

Table 4: Structure of Central Government Revenues (per cent of revenue)

\begin{tabular}{|c|c|c|c|c|c|c|c|c|c|c|c|c|}
\hline \multirow[t]{2}{*}{ Country } & \multicolumn{2}{|c|}{$\begin{array}{l}\text { Taxes on Income } \\
\text { Profits and capital } \\
\text { gains } \\
\end{array}$} & \multicolumn{2}{|c|}{$\begin{array}{l}\text { Taxes on goods } \\
\text { and services }\end{array}$} & \multicolumn{2}{|c|}{$\begin{array}{l}\text { Taxes on } \\
\text { international trade }\end{array}$} & \multicolumn{2}{|c|}{ Other taxes } & \multicolumn{2}{|c|}{$\begin{array}{c}\text { Social } \\
\text { Contributions }\end{array}$} & \multicolumn{2}{|c|}{$\begin{array}{l}\text { Grants and other } \\
\text { revenue }\end{array}$} \\
\hline & 1995 & 2007 & 1995 & 2007 & 1995 & 2007 & 1995 & 2007 & 1995 & 2007 & 1995 & 2007 \\
\hline Bangladesh & & 17 & & 28 & & 27 & & 4 & & & & 24 \\
\hline India & 23 & 41 & 28 & 29 & 24 & 15 & 0 & 0 & 0 & 0 & 25 & 15 \\
\hline Nepal & 10 & 13 & 33 & 36 & 26 & 16 & 4 & 4 & & & 27 & 30 \\
\hline Pakistan & 18 & 25 & 27 & 30 & 24 & 10 & 7 & 1 & & & 24 & 33 \\
\hline Sri Lanka & 12 & 18 & 49 & 48 & 17 & 14 & 4 & 5 & 1 & 1 & 18 & 13 \\
\hline Middle income & & 16 & & 38 & & 5 & & 1 & & 13 & & 15 \\
\hline $\begin{array}{l}\text { Lower middle } \\
\text { income countries }\end{array}$ & 19 & 17 & 34 & 39 & 14 & 5 & & 1 & & 10 & 16 & 16 \\
\hline $\begin{array}{l}\text { Upper middle } \\
\text { income countries }\end{array}$ & & 16 & & 37 & & 4 & & 1 & & 22 & & 14 \\
\hline South Asia & 15 & 18 & 31 & 29 & 24 & 15 & 4 & 2 & & 0 & 25 & 27 \\
\hline High income & 26 & 28 & 24 & 26 & & 0 & 3 & 2 & 35 & 34 & 9 & 9 \\
\hline
\end{tabular}

Source: Government Finance Statistics, IMF

Table 4 indicates, however, that the share of revenue collected from direct taxes is substantially lower in South Asian countries, with the exception of India in 2007, than in high income countries. In keeping with its recent high rates of economic growth the share of direct 
taxes in the revenues of the central government of India has climbed sharply (nearly doubled) between 1995 and 2007. The other South Asian countries for which we have data indicate more modest gains in this area. Taxes on goods and services were marginally higher in South Asian countries as compared to high income countries. But South Asian countries had lower commodity taxes to revenue ratio than those for all categories of middle income countries. Taxes on international trade fell between 1995 and 2007 for all South Asian countries but remained substantially higher than that in high income or middle income countries. Grants and other revenues in South Asia rose between 1995 and 2007 and were substantially in excess of the corresponding magnitude for high income and middle income countries.

\section{Sustainability of the Fiscal and Current Account Deficits in South Asian Countries}

Given the deficit and debt profile of the South Asian countries it behooves us to ask whether the fiscal deficit in these countries is sustainable. In addition, since the fiscal deficit spills over onto the external account it also becomes necessary to examine whether the current account deficit is sustainable. Jha (2004) discusses issues of sustainability in some detail. He works with the governmental intertemporal budget constraint. This is written in nominal terms as:

$$
G_{t}-T_{t}+r_{t} B_{t-1}=B_{t}-B_{t-1}
$$

Where $G_{t}$ is the value of government expenditures (purchases of goods and services plus transfer payments); $\mathrm{B}_{\mathrm{t}}$ is the government debt at the end of period $t, \mathrm{~T}_{\mathrm{t}}$ is the government's tax revenue and $r_{t}$ is the one-period rate of interest payable on the government debt. (1) states that in the absence of money finance, the government budget deficit must be financed by new debt creation. ${ }^{4}$ Hence, expressing (1) in terms of ratios to gross GDP we will have:

$b_{t}=\left(1+r_{t}\right)\left(1+\pi_{t}+\eta_{t}\right)^{-1} b_{t-1}+\left(g_{t}-\tau_{t}\right)$

Where the lower case letters denote the ratio of the corresponding uppercase variables to nominal GDP: $b_{t}=B_{t} / P_{t} Y_{t} ; g_{t}=G_{t} / P_{t} Y_{t}$; and $\tau_{t}=T_{t} / P_{t} Y_{t}$; with $P$ and $Y$ being the price level and real GDP respectively. $\pi_{\mathrm{t}}=\left(\mathrm{P}_{\mathrm{t}}-\mathrm{P}_{\mathrm{t}-1}\right) \mathrm{P}_{\mathrm{t}-1}$ is the rate of inflation and $\eta_{\mathrm{t}}=\left(\mathrm{Y}_{\mathrm{t}}-\mathrm{Y}_{\mathrm{t}-1}\right) / \mathrm{Y}_{\mathrm{t}-1}$ is the rate of growth of real GDP. In the derivation of (2) we have used the relation that: 
$P_{t} Y_{t}=\left(1+\pi_{t}\right)\left(1+\eta_{t}\right) P_{t-1} Y_{t-1} \approx\left(1+\pi_{t}+\eta_{t}\right) P_{t-1} Y_{t-1}$

$\left(\mathrm{g}_{\mathrm{t}}-\tau_{\mathrm{t}}\right)$ is the primary deficit (expenditures net of interest payments minus revenues) expressed as a percentage of GDP. In its empirical application sustainability requires that the revenue and expenditure series (if non-stationary which is usually the case) should be cointegrated with the cointegrating vector being $[1,-1]$. This would ensure that in the limit all public expenditures are financed by taxation and not by borrowing. Jha (2004) conducted these test for India, Nepal, Pakistan and Sri Lana for the periods 1952-1998, 1960-1996, 1955-1959, 1952-1998 respectively. For none of these countries was the sustainability condition satisfied. In a subsequent paper Jha and Sharma (2004) showed that the sustainability condition is satisfied for the case of India if we permit structural breaks in the time series for revenue and expenditure.

For the sustainability of the current account deficit it is necessary that, in the limit, all imports be financed by exports, i.e., in case exports and imports are non-stationary they should be cointegrated. Jha (2004) tested for the sustainability of the current account deficits in India and Pakistan for 1952-1997 and 1962-1998 respectively. Cointegration did not obtain in either case so that the current account for India and the trade balance for Pakistan was I(1).

The difficulty faced by South Asian countries in maintaining external balance implies that they need to attract capital inflows on a continual basis. This, in turn, requires that a wedge exist between domestic and foreign rates of return to capital. This, in turn, at least partially explains the high burden of interest payment in the South Asian countries as noted in Section II

In addition, high fiscal deficits in the South Asian countries lead to higher interest rates (thus crowding out private investment) and increase the burden of debt servicing. However, since bond markets in these countries are "thin" there are limits to the extent of bond financing of the deficit and often, non-bond (monetary) financing has to be resorted to. This leads to the development of a link between fiscal deficits and money supply and a compromising of the independence of monetary from fiscal policy (Jha, 2003).

This argument, if right, would indicate that there would exist a positive link between the fiscal deficit and budget deficit. Buffie (1999) demonstrates that this indeed is the case in many developing countries, including some from South Asia. 
Surely, an effective antidote to some of these issues is an effective deficit and debt reduction policy. Indeed, there is much to be said for this - tax rates need to be rationalized, tax loopholes closed, tax administration needs to be spruced up and wasteful current subsidies need to be curtailed. However, it is to be remembered (from Table 2) that South Asian countries spend a much smaller fraction of their revenues on subsidies than higher income countries. Hence, the scope for deficit reduction is probably limited. Managing the deficit under constant pressures for the expansion of government expenditure is one of the constants of economic life in the South Asian countries.

\section{Issues in Fiscal reform in South Asian Countries}

Two key issues related to fiscal policy are considered in this section. First, I discuss reasons for and a possible antidote for low tax/GDP ratios in South Asian countries. Second, I examine the scope for a VAT in these countries.

There are several reasons for the low tax/GDP ratios in South Asian countries. Most South Asian economies have large informal sectors. For instance, the Planning Commission of the Government of India estimates that well over 90 per cent of the Indian labor force is employed in the informal sector. This fact has important implications for tax design and effectiveness in these countries. In this context Auriol, and Warlters (2005) argue that such large magnitudes of the informal sector reflect difficulties in establishing enterprises in the formal sector. The existence of such high barriers to entry would imply that enterprises in the formal sector are acquiring large rents and can, hence, be taxed at relatively high rates. By the same token, it would be hard to tax a number of diffused small scale enterprises in the informal sector. The smaller the size of the rent earning formal sector the easier would taxation be and, therefore, the more lenient the policy to incorporate the informal sector economy into the formal sector. The larger size of the informal sector in developing countries arises from the higher costs of entry into the formal economy in developing countries. This argument is probably right for South Asian countries as witnessed by the slow pace of expansion of the formal labor market. However, long-run economic health would require that there be a rapid expansion of the formal sector. This would increase tax revenues, increase efficiency, encourage the adoption of more sophisticated tax instruments and ameliorate fiscal pressures. 
Further, a number of authors have argued that the rapid pace of globalization and technological advancement and the accompanying movement of factors of production have had the effect of reducing the tax base of many developing countries, including South Asian countries. For example, as Jha (2009c) notes the Indian economy has globalized rapidly during the past few years. In terms of openness to international trade the ratio of exports plus imports to GDP increased from by more than 50 per cent in the 10 years from 1997-98 to 2007-08 (from 21.2 per cent of GDP to 34.7 per cent of GDP). Furthermore, the growth of financial integration has been even more rapid. During the same 10 year period (1997-98 to 2007-08) the ratio of total external transactions (gross current account flows plus gross capital account flows to GDP) increased by more than 100 per cent from 46.8 per cent in 1997-98 to 117.4 per cent in 2007-08. Furthermore, corporate borrowing from external sources has also increased significantly. In 2007-08, for example, India received capital inflows to the extent of 9 per cent of GDP as against a current account deficit of 1.5 per cent of GDP. In particular, Lao-Araya (2003) has emphasized the role of multinational corporations in reducing tax bases for national and sub-national governments.

The literature now emphasizes the facts that with mobile capital, enterprise and labor governments are under pressure to protect their tax bases. Tax payers can now often raise resources from non-conventional sources and through channels other than the usual ones. Often, governments have to resort to tax competition to attract capital from non-conventional sources and through channels other than the usual ones. In all probability there will be more of this in the future. There does not seem to be an easy antidote for this except to encourage rules-based tax laws, good governance and greater cooperation with international taxation bodies.

I now address some antidotes to the low tax/GDP ratios in South Asian countries. In this context Jha (2006) reported that the unweighted average of tax buoyancy (defined as $\frac{\text { Percentage change intax revenue }}{\text { Percentagechange in taxbase }}$ ) for several developing countries, including India was greater than unity. An easily verifiable illustration of this is the fact that the tax to GDP ratio has climbed sharply in India following high growth rates in the period since 2004. Thus, the best antidote to a low tax to GDP ratio is rapid expansion of income, which at least partially, depends on the global business cycle. In addition to GDP there are political economy factors that impact upon the ability to raise taxes and, therefore, indicate possible ways to address 
this paucity. Gordon and $\mathrm{Li}$ (2005) make the simple but important point that taxation, by its very nature, has to depend on the formal economy, i.e., on the information available from bank records in order to identify taxable entities and to measure the amount of their taxable activity. If tax rates are too high firms and workers will be driven to the underground economy. In developed countries services provided by financial institutions are valued highly enough that such a move is deemed to be too costly. But, such a move may indeed be attractive in South Asian countries where the penetration of the financial sector is weak. Further, the tax base is likely to be narrow and cover mostly capital-intensive firms that need the financial sector the most. As a consequence the tax structure is likely to be biased towards capital income. Further, tariffs would be used to protect the capital intensive sectors and shortfalls in revenue (from public expenditures) would often be met through seigniorage, hence inflation would be high.

Jha (2009 b) argues that not only are fiscal variables more volatile for many developing countries, it is also the case that the movement of fiscal variables is pro-cyclical. Ideally, fiscal policy should be countercyclical. During recessions the government should be able to lower taxes and raise public expenditures to "spend" its way out of the recession whereas during good times, taxes can be raised and public expenditures reduced to reduce chances of overheating of the economy. This assumes that public borrowings are taken to be private wealth, an argument that is challenged by Barros' "Ricardian Equivalence” Hypothesis. Thus if Keynesian prescriptions are to be followed then fiscal policy should essentially be countercyclical, whereas if Barro type prescriptions were being followed there should essentially be no correlation between the phases of the business cycle and fiscal policy.

The Barro type prediction seems to be borne out for the G-7 countries whereas fiscal policy seems to be pro-cyclical in South Asia. The empirical evidence seems to suggest that for the G-7 countries the correlation between government consumption and outputs is indeed clustered around zero, substantiating the Barro principle. However, for many developing countries fiscal policy is actually procyclical which is neither Keynesian nor of the Barro type. Two explanations have been suggested for this phenomenon. Developing countries, including South Asian countries, have narrow tax bases whereas, and for political reasons, their public expenditures are inelastic. Thus public expenditures rise during boom times whereas during recessions revenues and expenditures both decline for similar reasons. Second, and as argued by Talvi and Vegh (2005), fluctuations in the tax base are much larger in developing countries than in developed countries. Thus, full tax smoothing of the Barro- 
type would require that there be large surpluses during good times. However, people realize this and when times are good exert strong political pressures to at least maintain, if not raise, the real values of public expenditures. Hence, the government is unable to raise the required surpluses. These pressures are particularly strong when times are good and can lead to cuts in tax rates, or increases in expenditures or both. Thus, fiscal policy becomes pro cyclical.

A final comment on tax reform deals with the issue of value added taxation. The VAT is being increasingly used in a number of developing countries including those in South Asia. The latest to do so is India, which has finalised plans to go to a VAT on $1^{\text {st }}$ April 2010. There are several reasons why the VAT is appealing to fiscal authorities. The most prominent advantage of the VAT is that since the tax base excludes inputs there is no cascading effect. To appreciate this consider the price paid for a refrigerator in the absence of a VAT. When the steel manufacturer sells steel to the refrigerator producer an excise duty is charged. Similarly when the final good — the refrigerator — is sold to a consumer an excise duty is charged. So the consumer pays tax twice - in fact she pays a tax on a tax (the duty paid on the tax inclusive price of steel paid by the refrigerator producer). This is, then, a cascading effect. Clearly, ceteris paribus, this is inefficient and would create incentives for vertical integration: the refrigerator producer would like to produce steel as well since this would reduce duty obligations. But, clearly this is inefficient since, ideally, the refrigerator producer should source steel from the most efficient producer. The VAT makes this possible and eliminates the incentive for vertical integration by enabling the write-off of duty paid at intermediate stages.

But is VAT then an efficient commodity tax? The answer is no.

Consider the case of a single rate VAT, although these arguments easily carry over to multi rate VATs, which are more common in developing countries and in being contemplated by India. The VAT is more difficult to impose on services than on goods, hence several services could escape the VAT tax net. In fact Karoleff et al. (1994) argue that in the case of the Canadian economy the underground sector accounts for somewhere between 14 and 22 per cent of the GDP. Piggott and Whalley (2001) while reviewing this literature opine that this figure may be exaggerated and the true value is between 7 and 8 percent of Canadian GDP. Nevertheless, this is a large magnitude. The corresponding figures for South Asian countries are likely to be much higher. 
Emran and Stiglitz (2005) raise an important argument against an uncritical use of VAT by considering the standard tax reform advocated by a number of international agencies, such as the IMF, as well as national governments in many developing countries to lower the trade tax and substitute for this a rise in the VAT to compensate for the loss in revenue. If all we had was the formal sector then this would lead unambiguously to a rise in the utility of the representative consumer since the economy would reap the benefits of trade reform which would more than compensate for any loss in utility from the rise in VAT. However, in the presence of an informal sector the base of the VAT is lower. Other things remaining the same, the smaller is the base of the VAT the greater would be the required hike in the rate of the VAT for any given reduction in trade taxes. This would then increase the chances that the loss in utility from the VAT increase would overwhelm the benefits from import tariff reduction. Emran and Stiglitz work out the appropriate thresholds for general tax reforms of this sort as well as reforms geared towards individual commodities.

Hence, there can be no unambiguous claim that the substitution of a VAT for trade taxes would increase welfare. ${ }^{5}$ Whether and how the VAT is to be implemented should ideally be guided by the contexts in specific countries.

\section{Conclusions}

This chapter has presented a brief overview of the extant fiscal situation in South Asian countries. In particular, I emphasized low tax/GDP ratios and inelastic expenditure/GDP ratios which then lead to structurally entrenched fiscal deficits. The chapter also reported on the sustainability of fiscal and current account deficits in the South Asian countries. Finally, the paper reports on some important issues in tax reform in South Asian counties. These include explaining and finding an antidote for low tax/GDP ratios and analyzing the scope for a VAT. Some general principles were enunciated but many of the required reforms would have to be context specific. 


\section{References}

Auriol, E. and M. Warlters (2005) 'Taxation Base in Developing Countries', Journal of Public Economics, 89(3), pp. 625-646.

Buffie, E. (1999) 'Public Sector Wage-Cycles and the Co-Movement of the Fiscal Deficit and Inflation in Less Developed Countries’, Journal of Money, Credit and Banking, 31(4), pp. 785-810.

Emran, S. and J. Stiglitz (2005) 'On Selective Indirect Tax Reform in Developing Countries', Journal of Public Economics, 89(3), pp. 599-623.

Gordon, R. and W. Li (2005) 'Tax Structures in Developing Countries: Many Puzzles and a Possible Explanation’, Working Paper 11267, National Bureau of Economic Research.

Jha, R. (2003) Macroeconomics for Developing Countries, second edition, London and New York: Routledge

Jha, R. (2004) 'The Macroeconomics of Fiscal Policy in Developing Countries', in T. Addison and A. Roe (eds) Fiscal Policy for Development: Poverty, Reconstructionand Growth, Basingstoke, UK: Palgrave Macmillan, pp. 24-45.

Jha, R. (2006) 'Pro-Poor Fiscal Policy in the Globalized Economy', in G.A. Cornia (ed.) Pro-poor Macroeconomics: Potential and Limitations, Basingstoke, UK: Palgrave-Macmillan, pp. 2748.

Jha, R. (2009a ) Modern Public Economics (second edn) London and New York: Routledge.

Jha, R. (2009b) 'Fiscal Policy', in A. Dutt and J. Ros (eds) International Handbook of Development Economics, London: Edward Elgar publishers, pp. 305-318. .

Jha, R. (2009c) 'The Global Financial Crisis and Short-run Prospects for India', ASARC Working Paper 2009/01, Australian National University. Available at http://rspas.anu.edu.au/papers/asarc/WP2009_01.pdf

Jha, R. And A. Sharma (2004) 'Structural Breaks, Unit Roots and Cointegration: A Further Test of the Sustainability of the Indian Fiscal Deficit', Public Finance Review, 32(2).

Karoleff, V, Mirus, R. and R. Smith (1994) 'Canada’s Underground Economy Revisited: Update and Critique’, Canadian Public Policy, 20(3), pp. 235-252.

Lao-Araya, K. (2003) 'Emerging Tax issues: Implications of Globalization and Technology', ERD Policy Brief No. 16, Asian Development Bank, Manila.

Lustig, N. (2002) 'Crisis and the Poor; Socially Responsible Macroeconomics', Economia 2000: 1(1) (Fall), pp.1-19.

Piggott, J. and J. Whalley (2001) 'VAT Base Broadening, Self Supply, and the Informal Sector', American Economic Review, 91(4), pp. 1084-1094.

Sah, R. (1983) 'How much redistribution is possible through commodity taxes?', Journal of Public Economics, 20(1), pp. 89-101.

Talvi, E. and C. Vegh (2005) 'Tax Base Variability and Procycilcal Fiscal Policy in Developing Countries', Journal of Development Economics, 78(1), pp.156-190. 


\section{Endnotes}

${ }^{1}$ Lustig (2002) argues that except for wars, economic crises have been the single most important cause of large increases in poverty.

${ }^{2}$ This, of course, does not mean that subsidies are well targeted. Indeed, the opposite seems to be the case in many developing countries, including South Asian countries (Jha, 2009b).

${ }^{3}$ This argument is subject to a caveat discussed in section IV below.

${ }^{4}$ The left hand side of the government's budget constraint must also include exchange rate changes and privatization which reflect changes in government net debt due to revaluation of the government's financial assets. In the empirical work reported in this paper this broader definition is used.

${ }^{5}$ For a simplified version of this argument see Jha (2009a). 